\title{
R\&D Investment Decision, Monetary Policy and Enterprise Productivity
}

\author{
Yan Zhao \\ School of Accounting \\ Fujian Jiangxia University \\ Fuzhou, China
}

\begin{abstract}
R\&D investment decisions and enterprise productivity are among the hot topics in the academic community; however the mediating role of monetary policy between R\&D investment decision and enterprise productivity is less studied by scholars. This article selects companies listed on the Shanghai and Shenzhen A shares from 2004 to 2017 as research samples, Total factor productivity based on the micro level of the enterprise, examines the impact of monetary policy and R\&D investment decision on productivity level. Empirical research results show: Monetary Policy Promotes R\&D Investment Decisions in Enterprises, Monetary policy has a positive effect on the improvement of enterprise productivity, R\&D investment increases business productivity, Monetary policy has a moderating effect between $R \& D$ investment decisions and corporate productivity.
\end{abstract}

Keywords-monetary policy; $R \& D$ Investment; enterprise productivity

\section{INTRODUCTION}

How to increase business productivity directly affects the profitability of the company, the increase of enterprise productivity depends on the enterprise's technological innovation and accumulation of knowledge information, and R\&D investment is one of the important ways to achieve technological innovation and knowledge accumulation. However, the company's own funds cannot meet the demand for R\&D investment, external financing is also an important source of funds for R\&D investment, but external financing is often influenced by monetary policy. In the process of corporate $\mathrm{R} \& \mathrm{D}$ investment decision-making, monetary policy has become an important factor in the decisionmaking of corporate R\&D investment. Therefore, exploring the mechanism of corporate R\&D investment decisions, monetary policy and business productivity, there is an important theoretical and practical significance for a deep understanding of how monetary policy affects corporate R\&D investment decisions and business productivity.

\section{LITERATURE REVIEW}

The relationship between monetary policy and corporate R\&D investment has long attracted academic attention; many scholars have conducted extensive research on this issue. In the absence of credit constraints, the proportion of R\&D investment in investment has anti-periodic characteristics (Aghion, 2007), Bank's support for R\&D continues to strengthen, Credit rationing has weakened the intensity of R\&D investment (Guo Hua, 2016), Austerity monetary policy can indirectly influence micro-enterprise R\&D investment behavior through accounting conservatism, Monetary policy impact will have an impact on R\&D investment, Both the appreciation of the effective exchange rate and the increase in the expected fluctuations are detrimental to the $R \& D$ investment of export enterprises (LiuQi Ren, 2017).

Domestic and foreign scholars have studied the relationship between monetary policy and total factor productivity. Research indicates: Monetary policy does have an impact on total factor productivity growth; monetary policy significantly affects total factor productivity growth, U. S. Federal Reserve System Launched Optimum Monetary Policy in the Face of Technical Shocks (Gatti, 2008), Monetary policy was positively correlated with total factor productivity, The appreciation of the RMB exchange rate has a positive effect on business productivity (XuJiayun, 2015), The higher enterprise productivity is the lower the exchange rate, The appreciation of the real effective exchange rate of the renminbi has promoted the total factor productivity of China's industries(Liu Ming, 2018).

The relationship between $R \& D$ investment and productivity has long attracted academic attention; the current research findings are mainly positive and negative. First, R\&D investment is conducive to improving productivity. Representative research results include: R\&D investment has a positive impact on Japanese manufacturing productivity, R\&D investment mainly influences productivity directly or indirectly through technological innovation and technology introduction, $R \& D$ has a longterm spillover effect on the total factor productivity of UK manufacturing(Anon, 2007), R\&D promotes total factor productivity growth (Kancs, 2016), R\&D investment shows a clear incentive for corporate total factor productivity, R\&D has a positive effect on productivity, $R \& D$ investment in SMEs has a significant positive effect on total factor productivity, R\&D capital investment in high-tech companies promotes local technological progress, The second is that $\mathrm{R} \& \mathrm{D}$ investment does not promote the improvement of enterprise productivity, achievements include: There is a negative effect between $R \& D$ and current 
productivity, Corporate innovation may not have a significant relationship with total factor productivity, R\&D investment hinders productivity growth, R\&D investment did not translate into improvement in total factor productivity, R\&D investment has a negative effect on business productivity(Huo Jie, 2014), R\&D investment growth has no significant negative impact on the growth of total factor productivity in manufacturing(Chen Fenglong, 2012).

In summary, the existing literature discusses the promotion effect of monetary policy on R\&D investment and productivity respectively and there is also a big difference in whether R\&D investments increase productivity. It has important reference and reference for understanding the mechanism of monetary policy and $R \& D$ investment on productivity. However, few existing literature consider the effect of monetary policy and R\&D investment on productivity at the same time. Based on, As a supplement to and extension of existing literature, This paper uses game analysis and real options to explore the mechanism of monetary policy, R\&D investment and productivity, Using statistical analysis to explore the effect of monetary policy, R\&D investment and productivity, This not only compensates for the gaps in related theoretical research to some extent, It also provides guidance and reference for the production and innovation practice of enterprises.

\section{THEORETICAL ANALYSIS AND RESEARCH HYPOTHESIS}

\section{A. $R \& D$ Investment Decisions and Monetary Policy}

Monetary policy is transmitted to companies through interest rate changes and credit rationing, Changes in interest rates and credit rationing determine the corporate financing environment, when monetary policy tightens, the reduction of money supply leads to a decrease in bank liquidity. Increased the market's real interest rate, Increased external financing costs, And due to the tightening of market liquidity, the ability of guarantees declined, Further increase the degree of corporate financing constraints, When monetary policy is loose, Increased market liquidity, Interest rates, Improved financing convenience, Corporate finance constraints are reduced.

Monetary policy affects corporate expectations, when the monetary policy has a high degree of uncertainty, companies cannot expect stable expectations for the future. Since corporate $\mathrm{R} \& \mathrm{D}$ is a complex system project, $\mathrm{R} \& \mathrm{D}$ requires a long-term sustained investment in large amounts of funds. Support of external financing from the enterprise is one of the important sources of funds for the company to carry out $R \& D$ investment. The $R \& D$ investment of the enterprise is often affected by the company's expectations. When financing is difficult or technical risks are high, the company may choose to withdraw from R\&D. The company is equivalent to obtaining an exit option. When the difficulty of financing is low or the technology risk is low, the company may choose to continue R\&D investment, and the company is equivalent to a call option. Corporate $R \& D$ investments have call options and exit options, and all options in the R\&D phase can constitute a compound option. When the uncertainty of monetary policy is low, companies can form relatively stable expectations and make R\&D investment decisions accordingly. When monetary policy tightens, companies reduce $\mathrm{R} \& \mathrm{D}$ investment, and expand $\mathrm{R} \& \mathrm{D}$ investment when monetary policy is loose. Based on the above analysis, this paper proposes Hypothesis 1 .

Hypothesis 1: Monetary policy is positively related to corporate $\mathrm{R} \& \mathrm{D}$ investment decisions.

\section{B. Monetary Policy and Business Productivity}

The main transmission channels of monetary policy are interest rate transmission and credit transmission. Monetary policy will affect the financing constraints of enterprises through the micro-level, and monetary policy affects the financing constraints from two aspects. First, from the aspect of interest rates, tightening the normal implementation of the currency has led to an increase in interest rates, Increased financing costs, difficulties in borrowing funds, and further deterioration of financing constraints. When monetary policy is more relaxed, the level of interest rates is reduced, and it is easier for companies to raise funds, which eases financing constraints. Second, from the aspect of credit, loose policies have eased the macro credit environment. Bank credit funds increase with the implementation of loose monetary policies, and loose monetary policies increase interest rates, Increased the company's net cash flow and equity prices, eased the financing constraints.

Due to the imperfect financial market, it is difficult for companies to obtain external funds with normal financing capital, resulting in insufficient financing. It is difficult to cope with changing market demands, making it possible to abandon the best investment opportunities in the business process, affects the trend of business activities. If the financing constraints faced by the industry are mitigated, this will help optimize the business operations of various companies in the industry and make it easier to raise funds for operating activities, To increase productivity. In the event of a shortage of funds, companies that are subject to financing constraints cannot make optimal business activity decisions, This distorts the allocation of resources, which in turn inhibits the increase in productivity. When the interest rate rises, the financing cost of the enterprise will increase accordingly, and the investment in the technological transformation of the enterprise will usually be larger. It often requires external financing to obtain the required funds, and companies are likely to abandon lucrative investment opportunities in the event of a shortage of funds, This distorts the efficiency of resource allocation and ultimately leads to lower productivity. The loose monetary policy has eased the financing constraints, optimized the allocation of resources, and thus promoted the improvement of productivity. Based on the above analysis, this paper proposes Hypothesis 2.

Hypothesis 2: Monetary policy is positively correlated with firm productivity. 


\section{Corporate $R \& D$ investment decision and enterprise productivity}

Innovation as an enterprise's endogenous behavior for profit, Innovation is a core element of the competitiveness and dynamic efficiency of an enterprise. $R \& D$ is the source of technological progress and technological innovation. $\mathrm{R} \& \mathrm{D}$ investment is a key driver of successful innovation and an important way to promote scientific and technological progress. R\&D activities create and accumulate knowledge, promote product innovation and process innovation, and provide a steady stream of motivation and support for productivity advancement. R\&D investment can not only directly generate new knowledge and information, but also enhance the ability of enterprises to absorb and learn existing knowledge and information, and promote the spillover of knowledge and technology. Enterprises can increase their R\&D investment to strengthen their internal technological capabilities so that they can follow up with the latest technological changes in a timely manner, promote assimilation of new technologies.

A well-developed market environment can usually enable reasonable allocation of $R \& D$ investment among industries and reduce corporate costs. Elimination of inefficiencies in corporate organization and management, companies invest in $\mathrm{R} \& \mathrm{D}$ to maintain technology leadership in the industry to obtain rent. The degree to which technological innovation can play a role depends on the level of intellectual property protection in the environment in which the company is located, and only in the environment where property rights protection is better. Technological innovation can really help companies gain competitive advantage, so that investment in the same resources can bring more operating income. The extent to which $\mathrm{R} \& \mathrm{D}$ investment can affect business productivity depends on two factors. The first is the innovation efficiency within the enterprise, that is, the ability of the enterprise to convert R\&D investment into technological innovation. The second is the intellectual property protection environment outside the enterprise, that is, the protection of the enterprise's technological innovation is not copied or imitated by the competitors, effectively improving the competitiveness of the enterprise. Since R\&D activities are a continuous process, it takes a certain amount of time from $R \& D$ investment to $R \& D$ output to the improvement of corporate efficiency. When companies and entrepreneurs find that R\&D investment can bring profits, they will invest in $\mathrm{R} \& \mathrm{D}$ activities. The main form of this income is the economic rent that can be obtained in imperfectly competitive markets. However, because enterprises and entrepreneurs cannot obtain the full benefits of their R\&D investment, this will result in the next generation of $R \& D$ investors being able to conduct research at a lower cost than their previous generation of $R \& D$ input. As a result, technological innovation can continue for a long time, thus drives continuous improvement in productivity. Based on the above analysis, this paper proposes Hypothesis 3.

Hypothesis 3: R\&D investment decisions are positively correlated with firm productivity.

\section{Monetary policy, $R \& D$ investment decision and enterprise productivity}

Since technical R\&D activities usually require the support of bank credit, there is a close relationship between interest rates and productivity. Technological innovation activities require large amounts of financial support. Companies that are the main driving force for technological $R \& D$ activities leave the external financing channels of banks and it is difficult to raise funds for R\&D activities in a short period of time. When interest rates rise, the cost of technology research and development activities will raise. Taking the profit factor into account, some companies will consider pushing back or canceling technology R\&D projects when the interest rate increases, resulting in a slowdown in productivity growth.

The risks encountered in the $R \& D$ investment of enterprises are mainly caused by batch investment and excessive time span. This article divides the $R \& D$ investment into two phases: $R \& D$ and production. If the $\mathrm{R} \& \mathrm{D}$ is successful, the company still needs to invest in infrastructure expansion and purchase of production materials. In this preparation process, corporate decision makers may obtain information on competition and alternatives, and thus adopt strategies such as changing the scale of investment or delaying investment or even exiting investment. Both stages of corporate $R \& D$ investment require capital investment, as the financing behavior of the company may be accompanied by the entire investment process. Under conditions of sufficient funds, such as the implementation of the first phase of $R \& D$ investment, the second phase of $R \& D$ investment rights is implemented. If the technical risks in the first stage are high or the financing is difficult, the company may choose to withdraw from $R \& D$, When the technology risk is low or the financing difficulty is small, the company may choose to continue $R \& D$ investment. At this time, the company is equivalent to obtaining a call option. Obviously, the first-stage call options and exit options cannot be executed at the same time. That is, all the options in the first phase can form one or more compound options. In the second stage, when adverse changes in market prices or financing are difficult, it may be decided to delay investment, expand or contract, or even withdraw investment. Therefore, if the call option is executed at the end of the first phase, then in the second phase, the company will receive delays, expansions, contractions, and exit options. The above options are independent and mutually exclusive. All options can form one or more compound options.

To simplify the problem, This paper builds a two-stage model based on a risk-neutral company that produces and sells a product in a market determined by demand, and assumes that the two-stage demand is independent of each other. In reality, the funds that companies have are limited, and it is impossible for companies to invest in $R \& D$ indefinitely. This article assumes that the amount of capital that the company has in the first phase is that the amount of funds owned by the company consists of the company's own retained funds, internal financing, and external borrowing under tight monetary policy. 
Set as $K=K_{1}+F_{1}+M x$

$K_{1}$ is expressed as the retained income for $R \& D$ investment owned by the enterprise.

$F_{1}$ is expressed as internal financing for R\&D investment by enterprises.

$M x$ represents the external borrowing of companies under monetary policy.

$M$ represents the monetary policy multiplier.

$x$ represents the maximum amount of external financing that companies can obtain.

In the first stage, the inverse demand function faced by enterprises is:

$$
P_{1}^{K}\left(Q_{1}^{K}\right)=S-Q_{1}^{K} \geq 0,
$$

In which, $S$ indicates the potential market size facing the company, $P_{1}^{K}$ indicate that the market of the enterprise is cleared in the first stage, $Q_{1}^{K}$ indicates the output of the company in the first phase, Enterprises need to make decisions in the first phase $Q_{1}^{K}$. And produce and sell the product at unit production cost $C(0 \prec C \prec S)$. In the first stage, companies also face the decision whether to invest in R\&D. Enterprises can choose to invest in $R \& D$ that reduces production costs or improves product quality, or they can simultaneously implement $R \& D$ investments that reduce production costs and improve product quality. In view of the long period required for $\mathrm{R} \& \mathrm{D}$ investment, this paper assumes that R\&D investment effects are only obtained in the second phase.

Assume that the company's $R \& D$ investment in reducing production costs is $R D_{1}^{K} \succ 0$. Investment in research and development to improve product quality $R D_{2}^{K} \succ 0$. The total production and $\mathrm{R} \& \mathrm{D}$ investment carried out by the company in the first phase is limited by the total amount of the company's funds, that is, meet:

$$
C Q_{1}^{K}+R D_{1}^{K}+R D_{2}^{K} \leq K .
$$

In order to meet the financial needs of enterprises for $\mathrm{R} \& \mathrm{D}$ investment in reducing production costs and improving product quality, enterprises need to have sufficient funds to carry out the first phase of production activities, namely $B \succ \frac{C(S-C)}{2}$.

In the second stage, the inverse demand function faced by the enterprise is:

$$
P_{2}^{K}\left(Q_{2}^{K}\right)=\left(1+\lambda R D_{2}^{K}\right) S-Q_{2}^{K} \geq 0 .
$$

Inside, $\left(1+\lambda R D_{2}^{K}\right) S$ expresses the potential market size that companies face in the second phase of investment in research and development to improve product quality.

Parameter $\lambda(0 \prec \lambda \prec 1)$ expresses the R\&D capabilities of enterprises in research and development activities to improve product quality. $\lambda$ larger means stronger R\&D capabilities.

The higher the investment $R D_{2}^{K}$ the bigger the market, the price and output of the company in the second phase of the market are paid out $P_{2}^{K}$ and $Q_{2}^{K}$. Enterprises need decision products $Q_{2}^{K}$ in Phase 2. And produce and sell the product at a unit cost of $\left(C-\alpha R D_{1}^{K}\right)$.

The parameters $\alpha(0 \prec \alpha \prec 1)$ indicate that the stronger the $R \& D$ capability of the enterprise project, with the increase of $\mathrm{R} \& \mathrm{D}$ investment $R D_{1}^{K}$, the lower the unit production cost. The goal of the enterprise is to maximize the total profit in two phases, in which the enterprise has a discount factor $\varphi(0 \prec \varphi \leq 1)$ for the second stage of income. Enterprise decision-making is essentially a trade-off between short-term and long-term benefits. Current R\&D investments reduce short-term profits but offer the possibility of long-term earnings growth. The joint decision of enterprise performance production and two kinds of R\&D investment aims to maximize the profits in two stages.

The profit function that the company faces in the first phase is:

$$
\begin{aligned}
& \operatorname{Max}^{K}\left(Q_{1}^{K}, R D_{1}^{K}, R D_{2}^{K}\right)=\left(S-Q_{1}^{K}{ }_{-} C\right) Q_{1}^{K} \\
& -R D_{1}^{K}-R D_{2}^{K}+\varphi Y_{2}^{K}\left(Q_{1}^{K}, R D_{1}^{K}, R D_{2}^{K}\right)
\end{aligned}
$$

The profit function of the company in the second phase is:

$$
\operatorname{Max}_{2}^{K}\left(Q_{2}^{K}\right)=\left[\left(1+\lambda R D_{2}^{K}\right) S-Q_{2}^{K}-C+\alpha R D_{1}^{K}\right) Q_{2}^{K}
$$

Because of $\frac{\partial Y_{2}^{K}\left(Q_{2}^{K}\right)}{\partial Q_{2}^{K}} \prec 0$, that is, $Y_{2}^{K}\left(Q_{2}^{K}\right)$ about the concave function $Q_{2}^{K}$. Can pass first-order conditions:

$$
\frac{\partial^{2} Y_{2}^{K}\left(Q_{2}^{K}\right)}{\partial Q_{2}^{K}}=\left(1+\lambda R D_{2}^{K}\right) S-Q_{2}^{K}-C+\alpha R D_{1}^{K}-Q_{2}^{K}=0
$$

The production decision of the company in the second phase is:

$$
Q_{2}^{K}\left(Q_{1}^{K}, R D_{1}^{K}, R D_{2}^{K}\right)=\frac{S-C+\alpha R D_{1}^{K}+\lambda S R D_{2}^{K}}{2}
$$

From formula(3), the output of the company in the second phase increases with the potential market size and its own increase in the two R\&D investments, and decreases with the increase in unit production costs.

The profits of the company in the second phase are:

$$
Y_{2}^{K}\left(Q_{1}^{K}, R D_{1}^{K}, R D_{2}^{K}\right)=\frac{\left(S-C+\alpha R D_{1}^{K}+\lambda S R D_{2}^{K}\right.}{4}
$$

The profit of the company in the second phase increases with the potential market size and its own investment in two kinds of R\&D, and decreases with the unit production cost.

Substituting (1) into(4) yields:

$$
\begin{aligned}
& \operatorname{Max}^{K}\left(Q_{1}^{K}, R D_{1}^{K}, R D_{2}^{K}\right)=\left(S-Q_{1}^{K}-C\right) Q_{1}^{K}-R D_{1}^{K} \\
& -R D_{2}^{K}+\frac{\varphi\left(S-C+\alpha R D_{1}^{K}+\lambda S R D_{2}^{K}\right)^{2}}{4}
\end{aligned}
$$


From formula(5), the optimization problem of the company in the first phase can be seen as the optimization of production and $\mathrm{R} \& \mathrm{D}$ investment, namely: $\operatorname{Max}^{K}\left(Q_{1}^{K}, R D_{1}^{K}, R D_{2}^{K}\right)=F^{K}\left(Q_{1}^{K}\right)+G^{K}\left(R D_{1}^{K}, R D_{2}^{K}\right)$

Among them, $F^{K}\left(Q_{1}^{K}\right)=\left(S-Q_{1}^{K}-C\right) Q_{1}^{K}$,

$G^{K}\left(R D_{1}^{K}, R D_{2}^{K}\right)=-R D_{1}^{K}-R D_{2}^{K}+\frac{\varphi\left(S-C+\alpha R D_{1}^{K}+\lambda S R D_{2}^{K}\right)^{2}}{4}$

Because of $\frac{\partial^{2} F^{K}\left(Q_{1}^{K}\right)}{\partial Q_{2}^{K^{2}}} \prec 0$, That $F^{K}\left(Q_{1}^{K}\right)$ is about the concave function $Q_{1}^{K}$, can pass first-order conditions:

$$
\frac{\partial F^{K}\left(Q_{1}^{K}\right)}{\partial Q_{1}^{K}}=S-Q_{1}^{K}-C-Q_{1}^{K}=0
$$

From formula (6), the output decision of the enterprise in the second phase, regardless of the type of R\&D investment, the optimal output of the enterprise in the first phase is:

$$
Q_{1}^{K}=\frac{S-C}{2}
$$

According to formula (7), the output of the first stage of the enterprise increases with the increase of the potential market size, and decreases with the increase of unit production costs. Due to the constraints faced by enterprises in the first phase of funding, that is $C Q_{1}^{K}+R D_{1}^{K}+R D_{2}^{K} \leq K$, substitution into the optimal production decision $Q_{1}^{K}$, available $R D_{1}^{K}+R D_{2}^{K} \leq K-\frac{C(S-C)}{2}$.

For simplicity, this article uses $K^{*}$ expresses:

$$
K-\frac{C(S-C)}{2} \text {. }
$$

According to hessian matrix positive definite, we can get the joint convex function $R D_{1}^{K}$ and $R D_{2}^{K}$ about sum $G^{K}\left(R D_{1}^{K}, R D_{2}^{K}\right)$, from which we get the boundary of the enterprise's optimal $R \& d$ investment decision is:

$$
R D_{1}^{K}+R D_{2}^{K}=K-\frac{C(S-C)}{2}=K^{*} .
$$

When the enterprise does not invest in research and development in both the first and second phases:

$$
R D_{1}^{K}=0, R D_{2}^{K}=0, G^{K}\left(R D_{1}^{K}, R D_{2}^{K}\right)=\frac{\varphi(S-C)^{2}}{4} .
$$

The output of the enterprise in the second phase is: the total profit in the two phases is:

$$
Y^{K}=\frac{(S-C)^{2}}{4}+\frac{\varphi(S-C)^{2}}{4} .
$$

When enterprises only invest in research and development through product quality:

$$
\begin{gathered}
R D_{1}^{K}=0, R D_{2}^{K}=K-\frac{C(S-C)}{2}=K^{*} \\
G^{K}\left(R D_{1}^{K}, R D_{2}^{K}\right)=-K^{*}+\frac{\varphi\left(S-C+\lambda S K^{*}\right)^{2}}{4}
\end{gathered}
$$

The output of the enterprise in the second stage is $Q_{2}^{K}=\frac{S-C+\lambda S K^{*}}{2}$, and the total profit of the two stages is $Y^{K}=\frac{(S-C)^{2}}{4}+\frac{\varphi\left(S-C+\lambda S K^{*}\right)^{2}}{4}-K$.

When enterprises only invest in research and development in reducing production costs, $G^{K}\left(R D_{1}^{K}, R D_{2}^{K}\right)=-K^{*}+\frac{\varphi\left(S-C+\alpha K^{*}\right)^{2}}{4}$.

The output of enterprises in the second stage is: $Q_{2}^{K}=\frac{S-C+\alpha K^{*}}{2}$.

The total profit of enterprises in the two stages is:

$$
Y^{K}=\frac{(S-C)^{2}}{4}+\frac{\varphi\left(S-C+\alpha K^{*}\right)^{2}}{4}-K
$$

Based on the above analysis, this paper puts forward hypothesis 4 .

Hypothesis 4: monetary policy and R\&D investment are positively related to productivity. Monetary policy has a positive adjustment effect between $R \& D$ investment and productivity.

\section{STUDY DESIGN}

\section{A. Sample selection and data sources}

This article uses the A-share companies listed on the Shanghai and Shenzhen Stock Exchanges from 2004 to 2017 as samples. The sample has been selected as follows: Removing companies with missing data; Excluding special financial companies; Deleting companies that are insolvent, ST; Company established more than 4 years. After screening, there are 1, 046 companies that meet the sample conditions. The monetary policy data comes from the website of the People's Bank of China and the China Financial Statistics Yearbook. And getting it by hand, this article performs Winsorize processing on $1 \%$ and $99 \%$ quantiles for continuous variables. Data processing uses Stata 14.0 and Execl 2016.

\section{B. Variable definition and measurement}

Definition and measurement of productivity

This paper first uses LP method, which is widely used by scholars, to measure productivity.

The definition and measurement of other variables are shown in "Table I". 
TABLE I. DEFINITION AND MEASUREMENT OF VARIABLES

\begin{tabular}{|c|l|l|}
\hline $\begin{array}{c}\text { Variable } \\
\text { name }\end{array}$ & $\begin{array}{c}\text { variable } \\
\text { symbol }\end{array}$ & \multicolumn{1}{c|}{$\begin{array}{c}\text { Variable } \\
\text { calculation }\end{array}$} \\
\hline $\begin{array}{c}\text { Total factor productivity of } \\
\text { enterprises }\end{array}$ & $T E P$ & Total factor productivity $=\frac{Y_{i}}{L_{i}^{\alpha} * K_{i}^{\beta}}, Y$ represents the company's operating income, L represents \\
all employees in the company, $K$ represents the net fixed assets at the end of the period.
\end{tabular}

\section{Research model design}

With reference to the relevant experience of existing literature, this paper will examine the basic quantitative regression model for the impact of monetary policy on $R \& D$ investment as follows:

$$
\begin{aligned}
& R D_{i, t}=\alpha_{0}+\alpha_{1} M P_{t}+\alpha_{2} F C_{i, t} \\
& +\alpha_{3} F C_{i, t} \times M P_{t}+\alpha_{4} R O A_{i, t} \quad \text { Model (1) } \\
& +\alpha_{5} T Q_{i, t}+\alpha_{6} \text { Lev }_{i, t}+\alpha_{7} \text { Size } \\
& +\alpha_{8} \text { Year }_{i, t}+\alpha_{9} \text { Industry }_{i, t}+\varepsilon_{i, t}
\end{aligned}
$$

$$
\begin{aligned}
& T E P_{i, t}=\lambda_{0}+\lambda_{1} M P_{t}+\lambda_{2} R D_{i, t} \\
& +\lambda_{3} R D_{i, t} \times M P_{t}+\lambda_{4} R O A_{i, t}+\operatorname{Model}(4) \\
& \lambda_{5} T Q_{i, t}+\lambda_{6} F C_{i, t}+\lambda_{7} \operatorname{Lev}_{i, t}+ \\
& \lambda_{8} \text { Size }_{i, t}+\lambda_{9} \text { Year }_{i, t}+ \\
& \lambda_{10} \text { Industry }_{i, t}+\zeta_{i, t}
\end{aligned}
$$

\section{EMMPIRICAL RESULTS AND ANALYSIS}

\section{A. Descriptive statistics and analysis}

"Table II" shows the descriptive statistics of the main variables. From the table, it can be seen that the average TFP of the company is 0.22 , and the maximum and minimum TFP are 0.315 and 0.013 , respectively, it shows that the current R\&D investment level of Chinese companies is not high, and the total factor productivity between companies is quite different. The standard deviation of $R \& D$ investment is 0.013 . It can be seen that the coefficient of variation is larger, the R\&D investment distribution of the company is more discrete, and the difference in the level of innovation between companies is more obvious. The maximum value of monetary policy is 0.291 , and the minimum value is 0.082 , indicating that the monetary policy differs greatly in different years. The maximum return on assets is 0.223 , and the minimum value is -0.006 , which means that the return on assets of the sample companies is quite different. The maximum value of the asset-liability ratio is 0.973 , and the minimum value is 0.018 , indicating that the sample company's asset-liability ratio is quite different. The maximum value of financing constraints is 0.464 , and the minimum value is 0.048 , which indicates that the sample companies have large differences in financing constraints. 
TABLE II. Descriptive Statistics of Major VARIAbles

\begin{tabular}{|c|l|l|l|l|}
\hline variable & Mean & $\begin{array}{c}\text { Standard } \\
\text { deviation }\end{array}$ & Maximum & Min \\
\hline$T E P$ & 0.022 & 0.276 & 0.315 & 0.013 \\
\hline$R D$ & 0.012 & 0.013 & 0.035 & 0.001 \\
\hline$M P$ & 0.136 & 0.124 & 0.291 & 0.082 \\
\hline$R O A$ & 0.102 & 0.089 & 0.223 & -0.006 \\
\hline Lev & 0.58 & 0.387 & 0.973 & 0.018 \\
\hline$F C$ & 0.226 & 0.087 & 0.464 & 0.048 \\
\hline
\end{tabular}

\section{B. Analysis of empirical results}

"Table III" gives the estimated results of the model (1) using a fixed effect model. The regression coefficient of monetary policy is 0.214 , and it is significant at the $1 \%$ level, indicating that monetary policy has a positive impact on $\mathrm{R} \& \mathrm{D}$ investment. The regression coefficient of financing constraints is -0.238 , and it is significant at the $1 \%$ level, indicating that companies with high financing constraints have difficulty in raising funds in their business activities and may abandon R\&D investment. The regression coefficient of the cross terms of monetary policy and financing constraints is 0.614 , and it is significant at the $1 \%$ level. Loose monetary policy can ease the financing constraints of enterprises and promote corporate $R \& D$ investment. Among the control variables, the regression coefficient of return on assets was 0.183 , the regression coefficient of asset-liability ratio was -0.146 , the regression coefficient of Tobin's Q was 0.217, and the regression coefficient of firm size was 0.114 , both of which were significant at the $1 \%$ level. The coefficient of return on assets is significantly positive, indicating that it can promote corporate R\&D investment. The coefficient of assets and liabilities is significantly positive and indicates that high corporate debt will inhibit R\&D investment. The coefficient of Tobin's $Q$ value is significantly positive, indicating that the market value of assets can promote $R \& D$. Investment, the scale of the company's scale is significantly positive, indicating that the greater the scale of the company's ability to increase the level of $R \& D$ investment. Hypothesis 1 is verified.

"Table III" gives the estimated results of the model (2) using a fixed effect model. The regression coefficient of monetary policy is 0.152 , and it is significant at the $1 \%$ level, indicating that a loose monetary policy can improve corporate productivity by alleviating corporate financing constraints. The regression coefficient of financing constraints is significantly negative, indicating that companies with high financing constraints may find it difficult to raise funds in their business activities. Enterprises may abandon lucrative investment opportunities and lower productivity levels. However, after adding the cross-terms of financing constraints and monetary policy, the coefficient of the cross item was found to be positive and significant at the level of $1 \%$, indicating that the effect of loose monetary policy to ease the financing constraints was significant. The coefficient of return on assets is significantly positive, indicating that companies with high levels of asset profitability have more funds for scale expansion, the introduction of new production equipment and technologies, etc. , thereby increasing the productivity of enterprises. The coefficient of Tobin's Q-value is significantly positive, indicating that the market value of assets can promote the improvement of enterprise productivity. The coefficient of firm size is significantly positive, indicating that the greater the scale, the greater the ability of the firm to increase productivity by reducing costs such as production and sales through economies of scale. The coefficient of asset-liability ratio is significantly negative, indicating that higher corporate capital risks and insecurity will reduce business productivity. Hypothesis 2 is verified.

"Table III" gives the estimated results of the model (3) using a fixed effect model. The regression coefficient of $\mathrm{R} \& \mathrm{D}$ investment is 0.734 , which is significant at the $1 \%$ level, indicating that $\mathrm{R} \& \mathrm{D}$ investment of enterprises has improved the productivity of enterprises by improving their independent innovation capabilities and their own technological level. From the regression coefficient of the control variables, it is evident that the return on assets has significantly promoted the improvement of enterprise productivity, the asset-liability ratio has inhibited the productivity of the enterprise, and the scale of the enterprise has significantly promoted the technological progress of the enterprise. Hypothesis 3 is verified.

"Table III" gives the estimated results of the model (4) using a fixed effect model. The regression coefficient of monetary policy is 0.316 , and it is significant at the $1 \%$ level, indicating that monetary policy can improve the business status of the company by alleviating financing constraints, thereby increasing the company's productivity. The regression coefficient of $R \& D$ investment is 0.668 , which is significant at the $1 \%$ level. This indicates that $R \& D$ investment can not only achieve the accumulation of independent technological innovation capability of enterprises through innovation effects, but also can improve the technological level through digestion and absorption and learning advanced foreign technologies, thus promoting Business productivity. The cross-item of $R \& D$ investment and monetary policy is used to measure the degree of capital constraint of R\&D investment. The coefficient represents the regulatory effect; the regression coefficient of the crossterm of R\&D investment and monetary policy is 0.138 , and it is significant at the $1 \%$ level, indicating monetary policy. There is a moderating effect between $R \& D$ investment and productivity. The coefficient of return on the return on assets is significantly positive, indicating that corporate profitability can help increase business productivity. The regression coefficient of Tobin's Q-value is significantly positive, indicating that the market value of the enterprise can promote the improvement of enterprise productivity. The regression coefficient of the asset-liability ratio is significantly negative, indicating that a higher level of corporate debt may inhibit the increase of enterprise productivity. The coefficient of regression of firm size is significantly positive, indicating that the economies of scale brought about by the scale of the firm contribute to the productivity of the firm. Hypothesis 4 is verified. 
TABLE III. EMPIRICAL RESULTS OF MONETARY POLICY, R\&D INVESTMENT AND PRODUCTIVITY

\begin{tabular}{|c|c|c|c|c|}
\hline variable & Model (1) & Model (2) & Model (3) & Model (4) \\
\hline$M P$ & $\begin{array}{c}0.214^{* * *} * \\
(3.18)\end{array}$ & $\begin{array}{c}0.152^{* * * *} \\
(4.19)\end{array}$ & & $\begin{array}{c}0.316^{* * * *} \\
(3.67)\end{array}$ \\
\hline$R D$ & & & $\begin{array}{c}0.734 * * * \\
(4.76)\end{array}$ & $\begin{array}{c}0.668^{* * * *} \\
(4.31)\end{array}$ \\
\hline$M P \times R D$ & & & & $\begin{array}{c}0.138^{* * * *} \\
(3.75)\end{array}$ \\
\hline$F C$ & $\begin{array}{r}-0.238^{* *} \\
(-3.16)\end{array}$ & $\begin{array}{r}-0.428^{* *} \\
(-2.96)\end{array}$ & $\begin{array}{c}-0.658 * * * \\
(-3.91)\end{array}$ & $\begin{array}{c}-0.614 * * * \\
(-4.56)\end{array}$ \\
\hline$M P \times F C$ & $\begin{array}{c}0.614^{* * * *} \\
(3.61)\end{array}$ & $\begin{array}{c}0.764 * * * \\
(3.96)\end{array}$ & & \\
\hline$R O A$ & $\begin{array}{c}0.183^{* * * *} \\
(3.17)\end{array}$ & $\begin{array}{c}0.089 * * * \\
(2.98)\end{array}$ & $\begin{array}{c}0.145^{* * * *} \\
(3.12)\end{array}$ & $\begin{array}{c}0.121 * * * * \\
(3.28)\end{array}$ \\
\hline Lev & $\begin{array}{c}-0.146^{* * * *} \\
(-3.13)\end{array}$ & $\begin{array}{c}-0.064 * * * \\
(-3.24)\end{array}$ & $\begin{array}{c}-0.107 * * * \\
(-3.75)\end{array}$ & $\begin{array}{l}-0.685^{* *} \\
(-3.19)\end{array}$ \\
\hline$T Q$ & $\begin{array}{l}0.217 \text { *** } \\
(3.26)\end{array}$ & $\begin{array}{l}0.128^{* * *} \\
(4.27)\end{array}$ & $\begin{array}{r}0.114 * * \\
(3.28)\end{array}$ & $\begin{array}{r}0.218^{* * *} \\
(4.28)\end{array}$ \\
\hline Size & $\begin{array}{r}0.114 * * \\
(3.18)\end{array}$ & $\begin{array}{r}0.081 * * \\
(3.25)\end{array}$ & $\begin{array}{r}0.074 * * \\
(2.98)\end{array}$ & $\begin{array}{r}0.052 * * \\
(3.17)\end{array}$ \\
\hline Constant term & $\begin{array}{r}-0.318^{* *} \\
(-3.23)\end{array}$ & $\begin{array}{r}-0.032^{* *} \\
(-4.13)\end{array}$ & $\begin{array}{r}-0.081^{* *} \\
(-3.18)\end{array}$ & $\begin{array}{r}-0.039 * * \\
(-3.72)\end{array}$ \\
\hline industry & commanded & commanded & commanded & commanded \\
\hline area & commanded & commanded & commanded & commanded \\
\hline years & commanded & commanded & commanded & commanded \\
\hline Adjusted $R^{2}$ & 0.3160 & 0.3460 & 0.3270 & 0.3620 \\
\hline$F$ value & 243.54 & 207.89 & 237.68 & 259.82 \\
\hline$P_{\text {value }}$ & 0.0000 & 0.0000 & 0.0000 & 0.0000 \\
\hline
\end{tabular}

${ }^{\text {a. }}$ Remarks: *, *** respectively indicate that they are significant at $5 \%$ and $1 \%$, and the of $\mathrm{t}$ statistic is shown in parentheses.

TABLE IV. Results of Monetary Policy, R\&D InVEstment, ANd PRoductivity Robustness Test

\begin{tabular}{|c|c|c|c|c|}
\hline variable & Model (1) & Model (2) & Model (3) & Model (4) \\
\hline$M P$ & $\begin{array}{c}0.162^{* * *} \\
(3.47)\end{array}$ & $\begin{array}{c}0.243^{* * * *} \\
(4.16)\end{array}$ & & $\begin{array}{c}0.034 * * * \\
(3.14)\end{array}$ \\
\hline$R D$ & & & $\begin{array}{c}0.569 * * * \\
(3.86)\end{array}$ & $\begin{array}{c}0.339 * * * \\
(3.94)\end{array}$ \\
\hline$M P \times R D$ & & & & $\begin{array}{l}0.129 * * * \\
(3.79)\end{array}$ \\
\hline$F C$ & $\begin{array}{r}-0.135^{* *} \\
(-3.32)\end{array}$ & $\begin{array}{l}-0.658^{* *} \\
(-3.29)\end{array}$ & $\begin{array}{l}-0.738 * * * \\
(-3.84)\end{array}$ & $\begin{array}{c}-0.652 * * * \\
(-3.56)\end{array}$ \\
\hline$M P \times F C$ & $\begin{array}{c}0.154 * * * \\
(3.17)\end{array}$ & $\begin{array}{c}0.156^{* * * *} \\
(3.89)\end{array}$ & & \\
\hline$R O A$ & $\begin{array}{c}0.152 * * * \\
(3.25)\end{array}$ & $\begin{array}{r}0.105^{* * *} \\
(3.25)\end{array}$ & $\begin{array}{r}0.051 * * \\
(3.04)\end{array}$ & $\begin{array}{r}0.061^{* *} \\
(3.12)\end{array}$ \\
\hline Lev & $\begin{array}{c}-0.418^{* * *} * \\
(-3.52)\end{array}$ & $\begin{array}{c}-0.358 * * * \\
(-4.14)\end{array}$ & $\begin{array}{c}-0.307 * * * \\
(-3.35)\end{array}$ & $\begin{array}{c}-0.303^{* * *} \\
(-3.78)\end{array}$ \\
\hline$T Q$ & $\begin{array}{l}0.157 * * * \\
(3.17)\end{array}$ & $\begin{array}{r}0.081 * * \\
(3.64)\end{array}$ & $\begin{array}{r}0.076^{* *} \\
(3.38)\end{array}$ & $\begin{array}{r}0.058 * * \\
(3.78)\end{array}$ \\
\hline Size & $\begin{array}{r}0.104^{* * *} \\
(3.43)\end{array}$ & $\begin{array}{r}0.053 * * \\
(3.41)\end{array}$ & $\begin{array}{r}0.014^{* *} * \\
(3.68)\end{array}$ & $\begin{array}{c}0.154^{* * * *} * \\
(3.48)\end{array}$ \\
\hline Constant term & $\begin{array}{r}-0.105^{* *} \\
(-3.18)\end{array}$ & $\begin{array}{r}-0.612^{*} \\
(-3.92)\end{array}$ & $\begin{array}{r}-0.624^{*} \\
(-3.82)\end{array}$ & $\begin{array}{r}-0.569^{*} \\
(-4.09)\end{array}$ \\
\hline industry & commanded & commanded & commanded & commanded \\
\hline area & commanded & commanded & commanded & commanded \\
\hline years & commanded & commanded & commanded & commanded \\
\hline Adjusted $R^{2}$ & 0.3040 & 0.3114 & 0.3416 & 0.3271 \\
\hline$F$ value & 252.01 & 295.34 & 281.15 & 273.28 \\
\hline$P_{\text {value }}$ & 0.0000 & 0.0000 & 0.0000 & 0.0000 \\
\hline
\end{tabular}

Remarks: $* * *$ respectively indicate that they are significant at $5 \%$ and $1 \%$, and the of $\mathrm{t}$ statistic is shown in parentheses. 


\section{Robustness test}

In order to test the robustness of the empirical results of this paper, this paper has tried the following tests: First, use the main business income to reduce the $R \& D$ investment; secondly, TFP is the core test variable of this paper. The ratio of operating income to the number of employees is used as an alternative measure of production efficiency; monetary policy indicators are expressed using narrow money supply (M1). The robustness test results are shown in "Table IV". From the robustness test results, the main regression results are consistent with the above empirical results.

\section{CONCLUSIONS}

This article is based on the micro data of Shanghai and Shenzhen A shares listed from 2004 to 2017, using the LP method to measure the productivity at the enterprise level, and examining the impact of monetary policy and R\&D investment on business productivity. The research conclusions show that there is a link between monetary policy and financing constraints. Monetary policy can promote corporate $\mathrm{R} \& \mathrm{D}$ investment by mitigating financing constraints. Monetary policy can improve business productivity by improving business performance; R\&D investment can improve innovation capabilities and technology transformation. Ability to achieve enterprise productivity improvement; monetary policy in the R \& D investment level and corporate productivity at the same time, monetary policy also has a moderating effect on the R \& D investment productivity conversion effect.

Based on the research conclusions, this paper puts forward three suggestions: First, related government departments formulate preferential R\&D investment policies, establish a fair and equitable business environment, and establish a sound institutional environment for innovation; Second, actively promote the marketization of interest rates and gradually eliminate The regulation of interest rates, actively playing a regulatory role in monetary policy, broadening corporate financing channels, alleviating financing constraints, and promoting the improvement of the productivity level of enterprises; Third, recommending that enterprises optimize the input structure of $R \& D$ investment and tightly integrate investment and financing mechanisms and conversion mechanisms, improve $R \& D$ investment productivity.

\section{ACKNOWLEDGEMENT}

This paper belongs to the project of the Fund Project. Fund Project Type: "Fujian Province Social Science Planning Projects"; Fund project number: FJ2015C170; Fund Project Name: Study on the R\&D investment effect of private enterprises under New Economic Norms.

This paper also belongs to the project of the Fund Project. Fund Project Type: "Fujian province Young and Middleaged Teachers Education Scientific Research Project”; Fund project number: JAS150633; Fund Project Name: Study on the Mechanism of New Economic Norms Influencing R\&D Investment of Private Enterprises.

\section{REFERENCES}

[1] Aghion, P. and Howitt, P. Appropriate growth policy: A unifying framework. Journal of the European Economic Association, 2007, (4):268-269.

[2] Anon Higon D. The Impact of R\&D Spillovers on Manufacturing TFP: A Dynamic Panel Approach. Research Policy, 2007, 36 (7):964-979.

[3] Chen Fenglong, Xu kangning. local market size and total factor productivity of Chinese manufacturing. China's Industrial Economy, 2012, (5): 44-56.

[4] Guo Hua, Zhang Bixi, Li Houjian. Legal environment, credit rationing and enterprise R\&D input. Macroeconomic Research, 2016, (9): 118-120.

[5] Gatti R., Love I. Does access to credit improve productivity? Evidence from Bulgaria. Economics of Transiton, 2008, 16(3): 445465.

[6] Huo Jie. The impact of domestic R\&D investment on total factor productivity in manufacturing. Science and Technology Management Research, 2014, (1): 130-132.

[7] Kancs A., Siliverstovs B. R\&D and non-linear productivity growth. Research Policy, 2016, 45(3):634-646.

[8] Liu Qiren, Huang Jianzhong. RMB exchange rate changes and research and development of export enterprises. Financial Research, 2017, (8): 19-21.

[9] Liu Ming, Li Xuesong, Sheng Ruxu. RMB exchange rate and industrial total factor productivity. Economic Issues Exploration, 2018, (1): 98 - 106

[10] Xu Jiayun, Tong Jiadong, Mao Qilin. RMB exchange rate and changes in enterprise productivity [J]. Financial Research, 2015, (10): $2-15$. 